Meta

Journal des traducteurs

Translators' Journal

\title{
Alcootest ou ivressomètre ? Deux études
}

\section{Anne Gérard, Serge Simoneau et Lois MacDonald}

Volume 23, numéro 3, septembre 1978

URI : https://id.erudit.org/iderudit/003528ar

DOI : https://doi.org/10.7202/003528ar

Aller au sommaire du numéro

Éditeur(s)

Les Presses de l'Université de Montréal

ISSN

0026-0452 (imprimé)

1492-1421 (numérique)

Découvrir la revue

Citer cet article

Gérard, A., Simoneau, S. \& MacDonald, L. (1978). Alcootest ou ivressomètre? Deux études. Meta, 23(3), 226-229. https://doi.org/10.7202/003528ar d'utilisation que vous pouvez consulter en ligne.

https://apropos.erudit.org/fr/usagers/politique-dutilisation/ 


\section{DROBLEMES ET SOLUTIONS}

\section{ALCOOTEST OU IVRESSOMÈTRE ? DEUX ÉTUDES}

L'emploi du terme "ivressomètre» est beaucoup contesté sous prétexte que l'on parle en France "d'alcootest »; mais ces deux termes désignent-ils réellement le même appareil?

\section{Les appareils}

On utilise en France un appareil qui permet de détecter, et seulement de détecter, la présence d'alcool dans le sang.

...(Le sujet) souffle, à l'aide d'un embout de verre stérilisé, dans un tube de verre contenant un réactif chimique jaune canari (oxyde de chrome et acide sulfurique mélangés à un sel de silice), relié à un ballon de contrôle en plastique. Lorsque le réactif est traversé par l'air contenant de l'alcool, il vire au vert ${ }^{1}$.

Par contre, au Canada, on se sert d'un appareil plus perfectionné qui effectue la détermination quantitative de l'alcoolémie et qui est calibré. C'est le Breathalyzer, baptisé ici «ivressomètre», qui utilise non pas l'oxyde de chrome et l'acide sulfurique; mais du bichromate de potassium dont la coloration est appréciée par deux cellules photoélectriques en opposition.

Notons qu'en France, la prise de sang est nécessaire si l'alcootest est positif, alors qu'au Québec elle est inutile, les résultats fournis par l'ivressomètre ayant valeur légale.

Il est donc normal, puisqu'on se trouve en face de deux appareils distincts, de vouloir les nommer différemment.

1. Quillet, Dictionnaire encyclopédique, Paris, Librairie Aristide Quillet, 1968, p. 147 (Définition donnée pour "alcooltest" ou "alcotest»). 


\section{Les termes}

"Alcootest": nous l'avons trouvé sous plusieurs formes: "alcootest ${ }^{2}$ », «alcotest ${ }^{3}$ ", « alcooltest ${ }^{4}$ », « alcool-test ${ }^{5}$ ». Il semble que l'usage ait consacré « alcootest» pour désigner à la fois l'épreuve biochimique et l'appareil qui permet de la réaliser. I1 aurait été plus juste de former un terme avec «éthanol ", puisque «alcool » est un terme générique et que le test ne porte que sur un type d'alcool: l'alcool éthylique, ou "éthanol". Ajoutons que "alcootest" était au départ une marque déposée qui est .devenue par la suite un nom commun.

"Ivressomètre": deux arguments sont le plus souvent avancés pour rejeter ce terme:

a) On ne peut utiliser « mètre" pour former un nom désignant un appareil qui ne fournit pas de mesures précises. Or, comme nous lavons vu, cette remarque est justifiée pour l'appareil en usage en France, mais pas pour celui utilisé au Canada.

b) L'ivresse est un état qui ne peut être mesuré. Cette objection est plus justifiée que la première; cependant, il existe une limite de $0,80 \mathrm{~g}$ par litre de sang (limite fixée par le législateur); une fois cette limite dépassée, le sujet est considéré comme « ivre». L'appareil en question permet bien d'évaluer si cette limite est dépassée et de combien.

Ainsi, ces deux termes sont, dans une certaine mesure, discutables. «Ivressomètre ", largement usité au Canada dans la presse, le public et les services de police est par ailleurs inconnu en France où on ne parle que "d'alcootest». Nous n'avons rencontré ce dernier terme au Canada que dans les textes publiés par le gouvernement fédéral. En conclusion disons que nous avons le choix entre:

a) étendre le sens " d'alcootest" afin qu'il englobe aussi le Breathalyzer; dans ce cas, il y aura polysémie ainsi que des difficultés d'implantation au Canada où «ivressomètre" est passé dans la langue courante.

b) conserver «ivressomètre" au Canada. Cette solution nous semble logique, puisque « l'alcootest » français n'est pas « l'ivressomètre ». Pourquoi alors chercher une uniformité lexicale qui ne correspond pas à la réalité?

ANNE GERARD

SERGE SIMONEAU

2. Alcootest: Code de la route, Les Editions Foucher, Paris, 1974, p. 133 ; Larousse, 3 vol., Librairie Larousse, Paris, 1965 , p. 71 ; Revue L'Auto-journal, $1977, \mathrm{n}^{\circ} 5$, p. $18 ; \mathrm{n}^{\circ} 11$, p. $20 ; \mathrm{n}^{\circ} 19$, p. 23.

3. Alcotest: Quillet, Dictionnaire encyclopédique, p. 147; Revue $L^{\prime}$ Auto-journal, $1977, \mathrm{n}^{\circ} 13$, p. 10 Larousse, 3 vol., 1965 , p. 71 .

4. Alcooltest : Dictionnaire des mots nouveaux, Hachette/Tchou, 1971, p. 14.

5. Alcool-test: Dictionnaire des mots nouveaux, 1971, p. 14. 
Both "alcooltest ' " and "ivressomètre" are used to ascertain the presence of alcohol in the blood stream by taking a breath sample of the person suspected of driving while under the influence of alcohol. By no means do they take the place of a blood sample but they do, however, immediately prove the innocence of those who have not been drinking.

The first distinction to be made between these two synonyms is geographical. The word "ivressomètre» could not be found in any dictionary published in Europe such as the Dictionnaire encyclopédique Quillet and the Dictionnaire des mots nouveaux. This lack of European representation gives more than a hint that this word is not used at all in French-speaking European countries. Furthermore, even though « alcooltest " does not figure in the latest edition of the Petit Robert (1976) it does have a place in the other two aforementioned dictionaries with documented examples of its use in Europe ${ }^{2}$. On the other hand, " alcooltest " is not found in the Dictionnaire général de la langue française au Canada ${ }^{3}$ where "ivresomètre" in defined. Preceding this definition is a symbol of the fleur de lys which corresponds, according to the editor, to "les canadianismes populaires... représentés dans notre langue familière par certains... mots ou expressions qui ne sont pas reçus dans le bon usage de la francophonie ${ }^{4}$ \%. The category of canadianisms in this dictionary was established in collaboration with l'Office de la langue française du Québec 5 . In addition to this definition of "ivressomètre" as a canadianism as well as the lack of its use in French-speaking European sectors is the abundance of its use in Quebec. In fact all the Quebec articles and periodicals concerning this subject, with the exception of Transports Canada, used solely «ivressomètre». The Criminal Code of Canada, being an official document, used "alcooltest". Furthermore, according to members of the MUC police as well as from the Ministry of Transport, "ivressomètre" is by far the more common word used. Therefore, it can be concluded that "ivressomètre " is a regionalism covering basically the same reality as that of the more accepted "alcooltest ".

The fundamental distinction between the two words is one of function. Whilst "alcooltest " applies to the breath analysis test as well as to the apparatus used for the test ${ }^{6}$, " ivressomètre" has a tendency to be used strictly for the apparatus ${ }^{7}$. Therefore, when speaking of the actual test either " se soumettre à l'épreuve de l'ivressomètre ${ }^{8}$ " or " au test de l'ivressomètre ${ }^{9}$ " must be used. There does not appear, however, to be a

1. Variations of the spelling of « alcooltest " include " alcootest " and " alcool-test ". From Pierre Gilbert, Dictionnaire des mots nouveaux, Hachette-Tchou, Paris, 1971, p. 14.

2. Ibid., page 14 and Dictionnaire encyclopédique Quillet, vol. 1, Librairie Aristide Quillet, Paris, 1968 , p. 147.

3. Dictionnaire général de la langue française au Canada, Bélisle, Editeur Inc., Québec, 1971, p. 668. 4. Ibid., p. 3 .

5. Ibid., p. 3.

6. Dictionnaire encyclopédique Quillet, vol. 1, 1968, p. 147.

7. Dictionnaire général de la langue française au Canada. 1971, p. 668.

8. Gérard Parizeau, "Les avatars de l'ivressomètre", Assurances, $40 \mathrm{e}$ année, $\mathrm{n}^{\circ} 2$, juillet, 1972, W.Y. O'Breham, Inc., Longueuil, page 147.

9. Pierre Béliveau, "Le droit de consulter un avocat avant de se soumettre à un test de l'ivressomètre ", la Revue du Barreau, vol. $35, \mathrm{n}^{\circ} 4$, sept. 1975, p. 445.

Claude Poulin, « Une injustice judiciaire!", le Réveil du consommateur, vol, 3, n 1, 1974, Journal Offset Inc., Montréal, p. 30.

R. Vallières, «La police peut séance tenante exiger le test de l'ivressomètre ", la Revue de la Sûrełé du Québec, vol. 4, n' 5, mai 1974, Montréal, p. 26. 
hard and fast rule about "ivressomètre" applying to just the apparatus since there are several examples where it denotes the test as well as the apparatus, as in « se soumettre à l'ivressomètre 10 ". In all these examples the contexts were quite similar thus negating any possibility that the differences between using «test / épreuve à l'ivressomètre " or simply "ivressomètre» to designate both test and apparatus could arise from the contexts. It is interesting to note that Transports Canada "1, in its study of two pilot programs undertaken to delve into the drinking habits of Alberta and New Brunswick drivers, uses both " alcooltest " and «ivressomètre». When discussing the test as well as the apparatus, the report uses "alcooltest" as in "des alcootests Stephenson, modèle 900 , ont servi à analyser les échantillons d'haleine ${ }^{12}$ 》. However, in the appendices, under the photographs showing the roadside stations, when no testing was in progress, " ivressomètre ${ }^{13}$ " was used.

It should now be clear that when speaking of the apparatus involved in taking breath samples to determine the presence of alcohol in the blood, "ivressomètre" is used in Quebec circles whereas "alcooltest " is used in French-speaking European regions as well as in Canadian official documents in French. The same regionalistic distinction applies when speaking of the actual breath analysis test. "Alcooltest" is applied in French-speaking European regions whilst in Quebec, the same reality is covered by either « test » or "épreuve» de l'ivressomètre or in some cases by «ivressomètre» itself.

LOIS MACDONALD

10. F. Chevrette et Marx, "Libertés publiques", la Revue du Barreau, vol. 32, n 4, sept. 1972, p. 446 Robert Borkenstein, «Problèmes d'application, jugements et sanctions en ce qui a trait aux Lois sur l'alcool et la sécurité routière"., Toxicomanies, vol. 8, $n^{\circ} \mathrm{I}$, jan.-mars 1975 , l'Office de la prévention de l'alcoolisme et des autres toxicomanies, Québec, p. 50.

11. Transports Canada, Alcool et Conduite, Information Canada, Montréal, 1974, p. (ii), 7, 8, 73, 75.

12. Ibid., p. 7.

13. Ibid., p. 73,75 . 